\author{
INFLUENCE OF VOICE INTONATION \\ ON UNDERSTANDING IRONY BY POLISH-SPEAKING \\ PRESCHOOL CHILDREN
}

\begin{abstract}
The main aim of the presented study was to investigate the influence of voice intonation on the comprehension of ironic utterances in 4- to 6-year-old Polish-speaking children. 83 preschool children were tested with the Irony Comprehension Task (Banasik \& Bokus, 2012). In the Irony Comprehension Task, children are presented with stories in which ironic utterances were prerecorded and read by professional speakers using an ironic intonation. Half of the subjects performed the regular Irony Comprehension Task while the other half were given a modified version of the Irony Comprehension Task (ironic content was uttered using a non-ironic intonation). Results indicate that children from the ironic intonation group scored higher on the Irony Comprehension Task than children who heard ironic statements uttered using a neutral voice. Ironic voice intonation appeared to be a helpful cue to irony comprehension.
\end{abstract}

Key words: intonation, irony, non-literal language

\title{
Introduction
}

Verbal irony is a figure of speech very commonly used to achieve various social and communicative goals (Kreuz \& Roberts, 1995; Leggit \& Gibbs, 2000). The speaker may decide to use an ironic utterance instead of a literal one in order to, for example, express criticism indirectly - a positive statement with a negative intended meaning (e.g., Dews, Kaplan, \& Winner, 1995). Therefore, as irony is widely used in our everyday communication, the ability to detect and understand this form of non-literal language is necessary in establishing and maintaining relations with others.

Address for correspondence: Maria K. Zajączkowska, School of Psychology, University of Kent, Keynes College, Canterbury CT2 7NP, UK. E-mail: mkz2@kent.ac.uk 


\section{Verbal Irony}

Although irony can be expressed by various forms of language, such as hyperbole, rhetorical questions, or understatements (Gibbs, 2000), most scholars define this form of figurative language as an utterance that is a semantic inversion of the literal (explicit) meaning and the intended (implicit) meaning (Anolli, Infantino, \& Ciceri, 2001). Barbe (1995) believes that one of the essential elements for comprehension and effective use of irony is the interlocutors' shared knowledge about the situational context. Additionally, irony detection is possible when speakers recognize the discrepancy between the literal and intended meaning.

\section{Irony Comprehension in Children}

Children acquire the ability to understand some forms of irony between the age of 5 and 6 years (Sullivan, Winner, \& Hopfield, 1995). Performance in irony comprehension tasks is assumed to be related to the theory of mind, that is, the ability to reason about mental states of others, such as emotions, beliefs, desires, and attitudes (Banasik, 2013; Happé, 1995). One of the forms of irony that is the easiest for a child to understand is sarcasm (Winner, 1988). Sarcastic comments are instances of irony that contradict the actual state of reality and are related to a mocking or scornful attitude towards the addressee (McDonald, 2000). Speakers very often use a special tone of voice to mark ironic comments (stress of a syllable or word, different pitch), which is seen as an important clue to ironic meaning (e.g., Glenwright, Parackel, Cheung, \& Nilsen, 2014).

\section{The Role of Voice Intonation in Irony Comprehension}

The ironic tone of voice is typically characterized by a strong intonation, slow tempo, and an underscored nasalization (Cutler, 1974). Though irony is unique among other modes of non-verbal communication in that it has its own, distinct tone of voice (Kreuz \& Roberts, 1993), its role in creating non-literal, ironic meaning is contested. Ackerman (1982) and Winner and Leekam (1991) claim that voice intonation is a neither necessary nor useful cue for irony and sarcasm comprehension. It is implied (Ackerman, 1982) that even young children who can detect sarcastic or ironic intonation might not be able to explain its meaning, as it requires complex inferring, deciphering, and integration of available information. Winner and Leekam found out that ironic voice intonation did not enable children (5-7-year-olds) to differentiate between irony and lie. However, there are numerous studies whose results suggest that the role of intonation in irony comprehension cannot be underestimated (e.g., Capelli, Nakagawa, \& Madden, 1990).

Tolmie and Rattray (2008) examined whether 3- and 4-year-olds rely on voice intonation as a cue for disbelieving lies and ironic jokes. The results 
suggest that 4-year-olds were able to decode a complex cue (ironic intonation) to beliefs of others and both 3- and 4- year-olds were capable of detecting the shift in voice intonation. The results were in line with Ackerman's (1982) thesis that detection and interpretation of ironic intonation are distinct processes. Capelli, Nakagawa, and Madden (1990) tested the role of voice intonation and context on irony comprehension in third graders, sixth graders, and adults. The results of the experiment showed that in acquiring an ability to interpret sarcasm, children rely more on voice intonation than on verbal context provided in the stories serving as experimental stimuli. Glenwright et al. (2014) proved in their study that the large reduction of fundamental frequency of voice intonation is a helpful cue for sarcasm interpretation for both adults and children.

\section{The Present Study}

Filippova(2014) suggests that theability to understand ironyvaries across socialand cultural contexts. Although there exist a few studies on the influence of voiceintonation on irony comprehension in English-speaking children, no research examining this phenomenon in Polish-speaking children was found. What is more, the majority of presented studies relied on statements uttered by the experimenter or by the participants themselves. Hence, it is difficult to determine whether the speaker's voice intonation possessed vocal features of irony or sarcasm throughout all of the experiments. To overcome this problem, each stimulus story in the present study was pre-recorded and uttered by a professional voice actor. Ironic voice intonation may have different vocal features (frequency, energy, time) depending on the context (Anolli, Infantino, \& Ciceri, 2002) and can be defined as a "voice of banter". For the purpose of this study, the speaker's ironic voice intonation ("blame by praise") was characterised by a high and changeable pitch, strong energy, and a slow rate of articulation.

The aim of this study was to determine whether there are differences in understanding ironic statements by Polish-speaking preschool children, depending on the voice intonation used by the speaker. Detailed analysis of the responses (accuracy, level of explanation of the speaker's intentions) enabled a verification of whether young children are sensitive to change in voice intonation and whether they use intonation as a cue for understanding ironic statements.

\section{Method}

\section{Participants}

Eighty-three Polish-speaking preschool children participated in the experiment (48 girls and 35 boys). The children were from 4 to 6 years of age $\left(\mathrm{M}_{\text {age }}=63.35\right.$ months, $M d n=62$ months, $\mathrm{SD}=5.359$ months $)$. All of the 
participants were recruited from public nurseries in Warsaw, Poland. Children from the control group were tested as part of a broader research project $^{1}$.

\section{Measures}

Children were tested with the Irony Comprehension Task (Banasik \& Bokus, 2012). In this task, children are presented with stories in which ironic utterances are read by professional speakers (male and female) using ironic voice intonation. The experimental materials consist of 12 stories that are presented on a touch screen. Each story is composed of three to five simple pictures. Six of the stories involve ironic utterances (critical comments that refer to the addressee or to the situation), while the other six involve literal statements. Half of the subjects performed the regular Irony Comprehension Task, while the other half was given a modified version using ironic utterances with neutral intonation).

In the basic version of the Irony Comprehension Task (Banasik, 2013; Banasik \& Bokus, 2012), one of the available cues for a child trying to understand the ironic statement is voice intonation. This cue is brought out in contrast with other neutral stories, in which there is no emphasis on voice intonation. However, in the modified version of the Task, the participant has to rely solely on the semantic meaning of the ironic statement, as voice intonation in all the stories is reduced and becomes neutral.

Each story describes everyday situations and involves two characters - a child and a family member or peer. After each story, a large question mark appears onscreen and the child is asked an open-ended question concerning the pragmatic function of the ironic utterance, "Why do you think [character's name] said that?" The next question ("When [character's name] said [ironic/ neutral utterance], did he mean that [literal meaning], or [intended meaning]?") is accompanied by additional onscreen illustrations, which represent two possible answers to the question - the literal meaning of the statement as well as the intentional meaning. The participant's task is to listen to the question and choose one of the two pictures that they consider to be the correct answer to the comprehension question.

\section{Procedure}

Each participant was tested individually by the same experimenter. The experiments were carried out in two public nurseries. The child was invited by the experimenter to a quiet room and seated in front of a touch screen. Children were told that they were going to play a computer game and solve some riddles. In the pre-test, the child was presented with a series of pictures on the screen

\footnotetext{
1 The research was conducted as a part of Natalia Banasik's research project: "Development of social reasoning in children. Understanding of verbal irony and theory of mind" financed by the Ministry of Science and Higher Education 2012-2015 (main supervisor: Barbara Bokus).
} 
and asked to touch the correct picture after they heard a question "Where is...?" The aim of this training was to familiarize the participant with the touch screen. After that, the experimenter explained to the child that he or she was going to solve some more riddles, and asked to listen carefully and answer some questions. After giving the instructions, the experimenter ran the task. The child's responses were saved and all sessions were audio-recorded.

\section{Data Coding}

For each comprehension question (e.g., "When [character's name] said: 'Oh! That's my favourite food', did she think that (a) she likes spinach and is happy to have it for dinner or that (b) she doesn't like spinach and is not happy to have it for dinner?"), the child received a score of 0 (incorrect response) or 1 (correct response) depending on the picture that was chosen. The maximum score attainable in the Irony Comprehension Task is 12.

The responses to the open-ended question ("Why do you think [character's name] said that?") regarding the pragmatic function of the ironic utterance were analysed and coded by three independent judges. Four main categories of explanations were noticed. Each of the categories reflects the child's level of reasoning about the speaker's intention:

0. Understanding of the situation; lack of reference to the discrepancy between the literal and intended meaning of the statement and to its function (e.g., "Because she didn't like it.")

1. Understanding of the situation and reference to the discrepancy between the literal and intended meaning (e.g., "Because for real it's not her favourite food but the worst one.")

2. Explicit reference to the speaker's intention, his/her mental states, or emotions (e.g., "Because she was lying that she liked that food.")

3. Metalanguage knowledge (e.g., "Because she was deceiving him, because sometimes you say like that even if he didn't come home early and he came back when it was very late.")

-1. Misunderstanding of the story; no response; "I don't know"

\section{Results}

\section{Irony Comprehension}

To examine the differences between the two groups (with and without ironic voice intonation), the Mann-Whitney test was carried out. The analysis of the overall results showed that there was a significant difference in irony comprehension between the groups $(N=83 ; p=0.001 ; U=515.000)$. The mean number of correct answers in the group in which ironic utterances were said with a corresponding ironic voice intonation was 11.24 (percentage $=94 \%$; 
$\mathrm{SD}=0.850)$. In the other group, in which ironic intonation was replaced by a neutral one, the mean score was 9.46 (percentage $=79 \%$; $\mathrm{SD}=2.758$ ).

The scores of both groups in six ironic stories were analysed with the Mann-Whitney test to examine whether voice intonation was an important cue for irony comprehension. Results showed significant differences between the groups in the six ironic stories $(N=83 ; p=0.008 ; U=603.000)$. The mean score of correct responses in the group where ironic voice intonation was present was 5.64 (percentage $=94 \%$; $\mathrm{SD}=0.577$ ). In the group where ironic statements were uttered with a neutral intonation, the mean score was 4.85 (percentage $=81 \%$; $\mathrm{SD}=1.574)$. Overall, these findings suggest that children understand ironic utterances better, that is, score higher on the Irony Comprehension Task, when ironic voice intonation is present in the stories.

Figure 1. Results on the Irony Comprehension Task for both groups (ironic and neutral voice intonation).

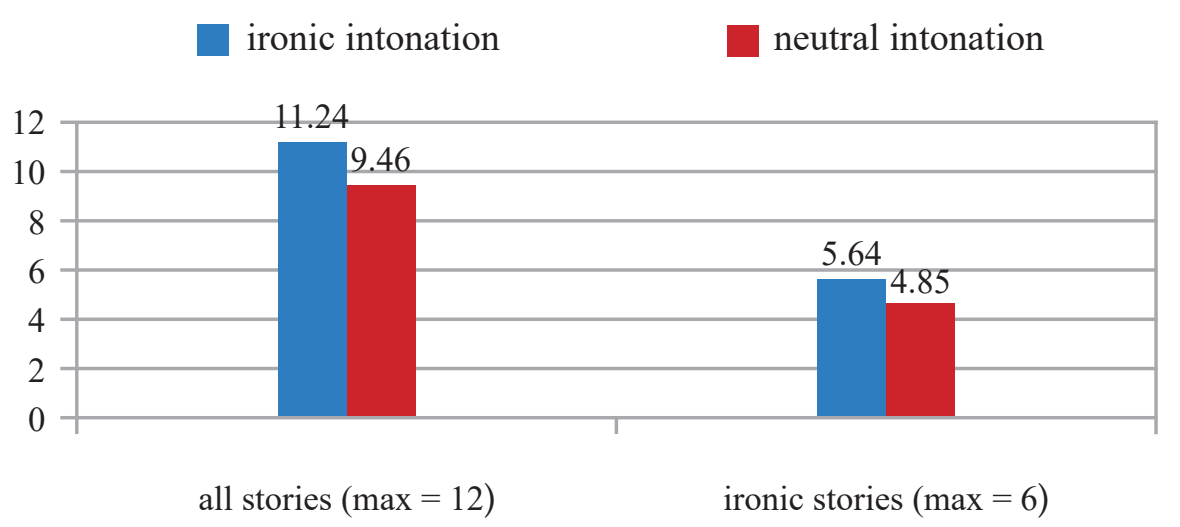

No significant differences based on gender were found in the group with neutral voice intonation $(N=42 ; p=0.097 ; U=158.000)$ nor in the group where the ironic statements were uttered with ironic intonation $(N=42 ; p=0.103$; $U=140.000)$.

The next set of analyses compared the scores obtained in the Irony Comprehension Task by 6-year-olds $(\mathrm{M}=68.83$ months; $M d n=69$ months; $\mathrm{SD}=1.586$ months $)$ and 5-year-olds $(\mathrm{M}=60.52$ months; $M d n=60$ months; 
$\mathrm{SD}=3.297$ months) in both groups (ironic voice intonation and neutral voice intonation). Responses for the six ironic stories were analysed. Five- and 6-year-olds from the group in which ironic stories were narrated with a corresponding ironic intonation did not differ significantly in the number of correct responses $(N=38 ; p=0.674 ; U=98.000)$. In the other group (neutral voice intonation), the differences in scores obtained by 5 - and 6-year-olds were also not significant $(N=41 ; p=0.479 ; U=142.000)$.

The results obtained by 5 -year-olds from the two groups (with and without ironic intonation) were also compared. Analysis with the Mann-Whitney test revealed significant differences between the two groups of 5-year-olds in the number of correct responses for the comprehension question $(N=56 ; p=0.019$; $U=261,000)$. In the group where children heard ironic stories with ironic intonation, the 5-year-olds scored higher than the 5-year-olds from the group in which ironic statements were uttered with neutral intonation. A similar analysis was carried out for the 6-year old children. However, performance was comparable between the two groups of 6-year-olds based on voice intonation used ( $N=23$; $p=0.185 ; U=39.000)$.

\section{Level of Explanations}

Participants' responses to the open-ended question "Why do you think [character's name] said that?" were analysed $(N=76)$. The children's explanations of the intended and literal meaning of the statement were categorised by three competent judges. The inter-rater reliability for the responses coded for the group with ironic intonation was $98 \%$; for the group with neutral intonation $91 \%$. The responses were divided into four categories depending on the level of explanations provided by the participant regarding the speaker's use of literal and intended meaning. The fifth category included the responses indicating a misunderstanding of the story.

The column proportions test analysis for independent samples revealed that in the group where ironic intonation was present there were significantly more responses from category 1 and category 2 than in the group with neutral intonation $(p<.05)$. Children from the group with ironic intonation referred to the discrepancy between the literal and the intended meaning, or mentioned the intentions of the speaker, his/her mental states, or emotions. Moreover, more responses from the second group (neutral intonation) were assigned to the category -1 , indicating a misunderstanding of the utterance $(p<0.05)$.

The answers given by 4-, 5-, and 6-year-olds were also analysed using the column proportions test. There were significant differences between the groups (ironic or neutral intonation) in the group of 5 -year-olds $(p<0.05)$. The analysis showed that in the group in which ironic statements were uttered with ironic intonation, more responses were assigned to the category 2 than in the group where ironic intonation was absent. In the first group, 18 responses (13\%) were 
Figure 2. Levels of explanations provided by the participant regarding the speaker's use of irony.

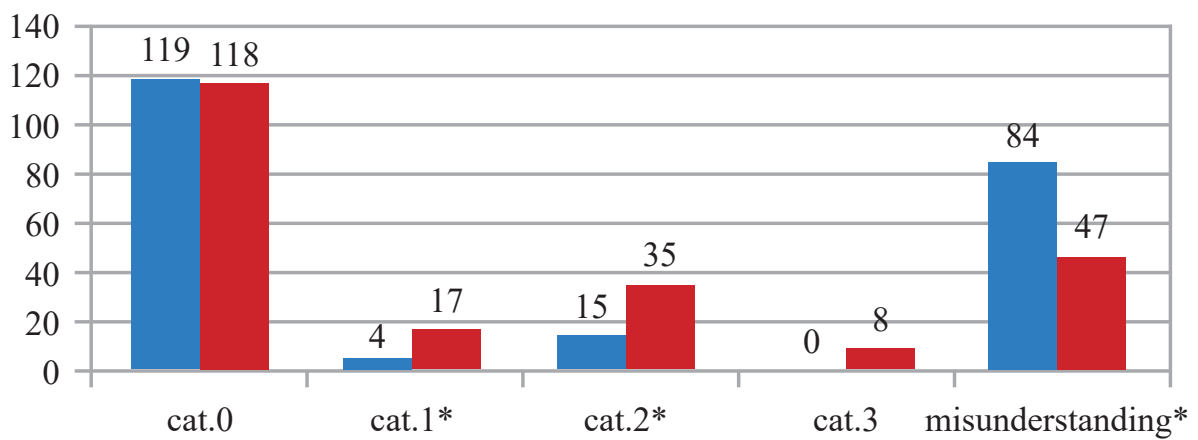

allocated to this category, while in the second group, only four responses (3\%). What is more, significantly more responses indicating a misunderstanding of the utterance were present in the group with neutral intonation $(43 \%$ in the group with neutral intonation; $22 \%$ in the group with ironic intonation).

Figure 3. Level of explanations provided by 5-year-olds regarding the speaker's use of irony.

neutral intonation ironic intonation

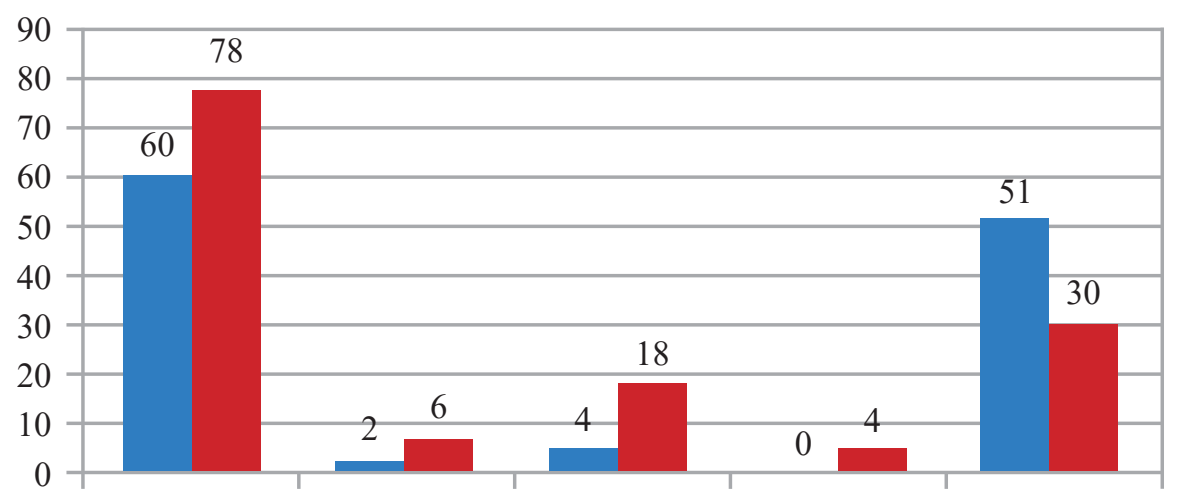

cat. 0

cat. 1

cat. $2^{*}$

cat.3 misunderstanding* 


\section{Discussion}

The present study explored the understanding of nonliteral language, in particular - verbal irony, by Polish-speaking preschool children. We investigated the ability of children to solve the Irony Comprehension Task (Banasik \& Bokus, 2012). Studies show that as children age, they develop the theory of mind, which enables them to differentiate between reality and a representation of reality in someone else's mind. A similar skill may be observed in the presented study on irony comprehension, when children acquire the ability to notice the discrepancy between the literal and intended meaning of the utterance. The Irony Comprehension Task enabled children to detect the intended (implicit) meaning fairly early. Children scored high on the Irony Comprehension Task - they were able to differentiate between the explicit and implicit meaning of the ironic statement.

As was hypothesized, the results of the study emphasize the role of intonation as a cue for detecting and understanding irony by preschool children. These children show substantially better understanding of a character's ironic statements (i.e., they score higher on Irony Comprehension Task) when the stories are accompanied by a corresponding ironic voice intonation. Group differences were significant both for the overall score and for the scores on the six stories consisting of ironic statements, and they are in line with current research (Glenwright et al., 2014; Tolmie \& Rattray, 2008).

Five-year-olds from the group in which ironic statements were uttered with a corresponding ironic intonation scored higher than 5-year-olds from the group with neutral intonation. This indicates that for 5-year-olds, voice intonation is an important cue that helps them in inferring the speaker's intentions. Contextual information that lacks marked ironic intonation is insufficient to help children comprehend the ironic utterance. Conversely, 6-year-olds do not rely on voice intonation when inferring the speaker's intended meaning of the ironic utterance.

Analysis of children's responses to the question "Why do you think [character's name] said that?" was an attempt at a thorough investigation of the mechanisms underlying irony comprehension. The results showed that the participants from the group in which ironic intonation was present gave more responses that referred to the mental or emotional state of the speaker, or his intentions, than did the participants from the group with neutral intonation. What is more, children from the group in which ironic intonation was replaced by neutral intonation answered in a way that indicated a misunderstanding of the utterance. Apparently, ironic voice intonation not only enabled children to understand the ironic utterance better but also facilitated more cognitively complex answers to the question regarding irony pragmatics.

The results of the presented study with Polish-speaking children provide evidence of differences in irony comprehension by preschool children depending 
on voice intonation used by the speaker. Regardless of the children's first language (in this case Polish), the essential conclusions are consistent with findings of international researchers. Studies with English-speaking children proved that voice intonation is a helpful cue for sarcasm interpretation (Glenwright et al., 2014) and for disbelieving lies or ironic jokes (Tolmie \& Rattray, 2008).

One of the limitations of the presented study is that it included only one type of this figurative language form, that is, ironic criticism. It seems justified to conduct further experiments using a more advanced version of the Irony Coprehension Task. This would enable researchers to determine whether a voice intonation cue is necessary for comprehending more complex forms of irony, such as hyperbole or understatement. Additionally, it would be interesting to analyse whether the professional speaker's gender may influence the understanding of this form of nonliteral language.

\section{References}

Ackerman, B.P. (1982). Contextual integration and utterance interpretation: The ability of children and adults to interpret sarcastic utterances. Child Development, 53 (4), 1075-1083.

Anolli, L., Infantino, M., \& Ciceri, R. (2001). You're a real genius! Irony as a miscommunication Design. In L. Anolli, R. Ciceri, \& G. Riva (Eds.), Say not to say: New Perspectiveson Miscommunication (pp. 141-163). Amsterdam: IOS Press.

Anolli, L., Infantino, M., \& Ciceri, R. (2002). From "Blame by Praise" to "Praise by Blame": Analysis of vocal patterns in ironic communication. International Journal of Psychology, 37 (5), 266-276.

Barbe, K. (1995). Irony in context. Pragmatics and beyond. Amsterdam, The Netherlands: John Benjamins Publishing.

Banasik, N. (2013). Non-literal speech comprehension in preschool children an example from a study on verbal irony. Psychology of Language and Communication, 17 (3), 303-323.

Banasik, N. \& Bokus, B. (2012). Measuring the understanding of verbal irony in children. Poster presented at the Conference Psycholinguistics in Flanders, Berg en Dal.

Capelli, C., Nakagawa, N., \& Madden, C. (1990). How children understand sarcasm: The role of context and intonation. Child Development, 61 (6), 1824-1841.

Cutler, A. (1974). On saying what you mean without meaning what you say. In M. Galy, R. Fox, \& A. Bruck (Eds.), Papers from the Tenth Regional Meeting, Chicago Linguistic Society (pp. 117-127). Chicago, Ill.: CLS.

Dews, S. \& Winner, E. (1995). Muting the meaning: a social function of irony. Metaphor \& Symbolic Activity, 10 (1), 3-19. 
Filippova, E. (2014). Developing of appreciation of irony in Canadian and Czech discourse. Fournal of Pragmatics, 74, 209-223.

Gibbs, R.W. (2000). Irony in talk among friends. Metaphor and Symbol, 15, 5-27. Glenwright, M., Parackel, J.M., Cheung, K.R., \& Nilsen, E.S. (2014). Intonation influences how children and adults interpret sarcasm. Journal of Child Language, 41 (2), 472-484.

Happé, F.G.E. (1995). Understanding minds and metaphors: Insights from the study of figurative language in autism. Metaphor and Symbolic Activity, $10(4), 275-295$.

Kreuz, R.J. \& Roberts, R.M. (1993). On satire and parody: The importance of being ironic. Metaphor and Symbol, 8 (2), 97-109.

Kreuz, R.J. \& Roberts, R.M. (1995). Two cues for verbal irony: Hyperbole and the ironic tone of voice. Metaphor and Symbolic Activity, 10 (1), 21-31.

Leggitt, J.S. \& Gibbs, R.W. (2000). Emotional reactions to verbal irony. Discourse Processes, 29 (1), 1-24.

McDonald, S. (2000). Neuropsychological Studies of Sarcasm. Metaphor and Symbol, 15 (1), 85-98.

Sullivan, K., Winner, E., \& Hopfield, N. (1995). How children tell a lie from a joke: The role of second-order mental state attributions. British Journal of Developmental Psychology, 13 (2), 191-204.

Rattray, C. \& Tolmie, A. (2008). Young children's detection and decoding of ironic intonation. Psychology of Language and Communication, 12 (1), 29-54.

Winner, E. (1988). The point of words: Children's understanding of metaphor and irony. Cambridge, MA: Harvard University Press.

Winner, E. \& Leekam, S. (1991). Distinguishing irony from deception: Understanding the speaker's second-order intention. British fournal of Developmental Psychology, 9(2), 257-270.

\section{Appendix}

\section{The stories with ironic statements (original in Polish)}

\section{Historyjka 1}

Staszek i Piotrek bawią się na podwórku. Staszek się przewraca. Wstaje, a jego spodnie są mokre i całe w błocie. „Ale jesteś czysty”- mówi Piotrek.

1. Jak myślisz, dlaczego Piotrek tak powiedział?

2. Czy kiedy Piotrek powiedział: „Ale jesteś czysty”, to miał na myśli, że:

A. Staszek nie pobrudził się i jest czysty

B. Staszek się pobrudził i nie jest czysty 


\section{Historyjka 2}

Krzyś chciał napić się soku. Poprosił brata o sok. Brat nalał soku do szklanki. Krzyś przewrócił szklankę i wylał sok na czysty obrus. Zrobiłą się duża mokra plama. „Świetnie się spisateś” - powiedział brat do Krzysia.

1. Jak myślisz, dlaczego brat tak powiedział?

2. Czy kiedy brat powiedział: „Świetnie się spisałes”, to miał na myśli, że:

A. Krzyś dobrze zrobił i brat się z tego cieszy

B. Krzyś niedobrze zrobił i brat się z tego nie cieszy

\section{Historyjka 3}

Julek miał przyjść do domu prosto ze szkoły. Babcia czekała na Julka. Jest już wieczór i za oknem ciemno. Julek wraca do domu. „O, jak szybko wróciteś do domu" - powiedziała babcia.

1. Jak myślisz, dlaczego babcia tak powiedziała?

1. Czy kiedy babcia powiedziała: „O, jak szybko wróciteś do domu”, to miała na myśli, że:

A. Julek wrócił wcześnie do domu i babcia nie czekała na niego długo

B. Julek wrócił późno do domu i babcia czekała na niego długo

\section{Historyjka 4}

Wujek zawsze przynosi Zuzi prezent. Dziś przyniósł dużą spinkę do włosów. Wujek pamięta długie włosy Zuzi. Nie wie, że mama wczoraj obcięła Zuzi włosy. Dziewczynka ma teraz krótkie włosy. Wujek zobaczył Zuzię i woła:

„Ojoj! Ale urosty Ci wtosy!”

1. Jak myślisz, dlaczego wujek tak powiedział?

2. Czy kiedy wujek powiedział: „Ojoj! Ale urosty Ci wtosy!”, to miał na myśli, że:

A. włosy Zuzi urosły i są długie

B. włosy Zuzi są obcięte i są krótkie

\section{Historyjka 5}

Krzyś wraca z mamą z przedszkola. Chcą szybko wrócić do domu. Zaczyna padać deszcz. Mama z Krzysiem biegną do autobusu, ale drzwi autobusu się zamknęly. Autobus odjechał bez nich. „Dziś naprawdę mamy szczęście”- powiedziała mama.

1. Jak myślisz, dlaczego mama tak powiedziała?

2. Czy kiedy mama powiedziała: „Dziś naprawdę mamy szczęście”, to miała na myśli, że:

A. Mamie i Krzysiowi wszystko się dziś udaje i mają szczęście

B. Mamie i Krzysiowi nic się dziś nie udaje i nie mają szczęścia

\section{Historyjka 6}

Gosia bardzo nie lubi szpinaku. W przedszkolu nigdy go nie zjada. Dziś na obiad jest szpinak. Gosia mówi do koleżanki: „O, moje ulubione jedzenie”. 
1. Jak myślisz, dlaczego Gosia tak powiedziała?

2. Czy kiedy Gosia powiedziała: „O, moje ulubione jedzenie”, to miała na myśli, że:

A. bardzo lubi szpinak i cieszy się z obiadu

B. nie lubi szpinaku i nie cieszy się z obiadu

\section{The stories with ironic statements (in English)}

\section{Story 1}

Steve and Tom are playing in the backyard. There are puddles and there is mud on the ground. Steve falls down. He stands up and his pants are wet and muddy. 'You are so clean!', says Tom.

1. Why do you think Tom said this?

2. When Tom said 'You are so clean!', did he mean:
A. Tom did not get dirty and is clean.
B. Tom got dirty and isn't clean.

\section{Story 2}

Chris wanted to have some juice. He asked his brother for the juice. Chris' brother poured him a glass of juice. Chris knocked down the glass and spilled the juice over the clean tablecloth. There was a big, wet stain on the tablecloth. 'Well done!', said the brother to Chris.

1.Why do you think Chris' brother said this?

2. When Chris' brother said: 'Well done!', did he mean:

A. That Chris did something well and his brother is happy with that.

B. That Chris did something bad and his brother is not happy with that.

\section{Story 3}

Jerry was supposed to come straight home after school. His grandma has been waiting for him. It gets dark outside. Jerry gets home. 'You got back so soon!', says Jerry's grandma.

1. Why do you think Jerry's grandma said this?

2. When Jerry's grandma said: 'You got back so soon!', did she mean:

A. Jerry came home soon and his grandma has not been waiting for him.

B. Jerry came home late and his grandma has been waiting for him.

\section{Story 4}

Susie's uncle always brings her a present. Today he brought her a scrunchy. Susie's uncle remembers that Susie had long hair. He does not know that Susie's mum cut Susie's hair yesterday. Now Susie has short hair. When the uncle sees Susie, he says: 'Your hair is so long!'. 
1. Why do you think Susie's uncle says this?

2. When Susie's uncle said: 'Your hair is so long!', does he mean that:
A. Susie's hair has grown and it is long.
B. Susie's hair was cut and it is short.

\section{Story 5}

Johny is coming back from preschool with his mum. They want to get back home soon. It starts raining. Johny and his mom are running to catch their bus. But the bus door closes, the bus leaves without them. 'We are so lucky today!', says Johny's mum.

1. Why do you think Johny's mum said this?

2. When Johny's mom said: 'We are so lucky today!', did she mean that:
A. Everything went well and Johny and mom are lucky today.
B. Everything went wrong and Johny and mom are not lucky today.

\section{Story 6}

Maggie thinks spinach is yucky. She never eats it. They are having spinach for lunch today. Maggie does not want to eat the spinach. She says to her friend, 'Oh! my favourite food!'.

1. Why do you think Maggie said this?

2. When Maggie said: 'Oh! my favourite food!', did she mean that:
A. She likes spinach very much and is enjoying lunch.
B. She does not like spinach and is not enjoying lunch. 